\title{
HOUSEHOLD LOGISTICS IN TOURISM SUPPLY CHAIN
}

\author{
Snežana Tadić 1 \\ Miloš Veljović ${ }^{2}$
}

DOI: https://doi.org/10.31410/tmt.2020.67

\begin{abstract}
The tourism supply chain (TSC) consists of different participants: suppliers, tour operators and customers; in TSC, numerous physical and information flows to end customers are realized. Efficient realization of flows is enabled by logistics systems and technologies. In this way, logistics contribute to the competitiveness of tourism products. TSC participants can be trade, production, catering, logistics companies, travel agencies, but also households, primarily in rural areas. Households can play a role at all levels of TSC (suppliers of goods, materials and services, tour operators, travel agencies, end customers) and in various forms of tourism, but they play the most important role in rural and agritourism. Logistics is important in the optimization of logistics flows of households in TSC, having in mind imperatives of quality of goods, services, or complete tourism products that they can supply customers with. Therefore, in this paper, the role, significance and basic characteristics of subsystems of household logistics in TSC are analyzed.
\end{abstract}

Keywords: Tourism supply chain, Agri-food supply chain, Rural household, Logistics subsystems, Rural tourism, Agritourism.

\section{INTRODUCTION}

$\mathrm{T}$ ourism involves the travel and stay of people outside the usual environment, which is temporary (Mathieson \& Wall, 1982), i.e. lasts up to a year (United Nations - World Tourism Organization, 1994). The grow th and development of the tourism sector have been stimulated in recent decades by various social and economic factors (Tadić \& Veljović, 2020b): globalization, development of information and communication technologies (ICT), development of transport infrastructure, better living standards and more free time, consumerism and hedonism, the offer of new tourist services and contents, etc. On the other hand, tourism has increasing importance in the socio-economic development of regions and countries (Szpilko, 2017). As tourism is not a pure manufacturing industry or a pure service industry (Jafari, 1974; Page, 2009; Zhang \& Murphy, 2009; Piboonrungroj \& Disney, 2009), the tourism product is a combination of goods and services (Piboonrungroj \& Disney, 2009; Tadić et al., 2012).

The tourism supply chain (TSC) is a network of tourism organizations engaged in various activities, from offering different components of tourism products/services such as flights and accommodation to the distribution and marketing of the final tourism product at a specific tourism destination, and involves a wide range of participants in both the private and public sectors (Zhang et al., 2009). The main intermediaries between end customers and suppliers of goods and services are travel agencies, which sell tourism products, and tour operators, which in addition to sales also organize logistics activities in order to provide the tourism product to

\footnotetext{
1 University of Belgrade, Faculty of Transport and Traffic Engineering, Vojvode Stepe 305, 11000 Belgrade, Serbia

2 University of Belgrade, Faculty of Transport and Traffic Engineering, Vojvode Stepe 305, 11000 Belgrade, Serbia
} 
the end customer at the right time, in the right place, under the most favorable conditions (Tadic \& Veljović, 2020b). In this context, tour operators can be considered 4PL providers (Piboonrungroj \& Disney, 2009).

In TSC, physical (flows of goods, materials and freights) and information flows to end customers are realized (Piboonrungroj \& Disney, 2009). The quality and competitiveness of the tourism product depend on the optimization of flows (Mrnjavac \& Ivanovic, 2007) and the application of logistics principles and technologies (Tadić \& Veljović, 2020b). Tourism logistics can be defined as the science of planning, controlling and managing operations performed during the process of preparing a tourist offer, delivering the finished product to the customer following his interests and requirements, as well as during the process of transferring, storing and processing information about these activities (Kochadze et al., 2013).

In addition to end customers, travel agencies and tour operators, TSC consist of numerous suppliers of goods and services at various tiers. TSC participants can be trade, production, service, catering, logistics, marketing and other companies, cultural and educational institutions, but also households. Households can be TSC participants at various tiers. In addition to supplying goods, materials and services, households can perform the functions of tour operators and travel agencies, i.e. create and sell complete tourism products, but also be end customers of them.

Households usually have the role of suppliers of goods and materials. They can supply other participants in the supply chain of natural resources, agricultural, food, handicraft products and raw materials, souvenirs, etc. In order to reduce logistics costs, affirm local production and ensure the safe origin and quality of goods, companies usually buy goods from rural households in the immediate vicinity. Therefore, goods and materials from households are most often used by participants in the supply chain in rural tourism, but often also by participants in supply chains in other forms of tourism (urban, coastal, etc.).

The expectations and demands of tourists are increasingly diverse. Thus, they not only want to change the location, but also the ambience, everyday life, and even to „travel through time”. Therefore, a significant role in the tourist offer is played by cultural and historical monuments, the natural environment, but also the rural, countryside ambience and way of life. In recent decades, various forms of rural tourism have been intensively developed, which includes all tourist services and activities in rural areas, which do not have an urban character (tourism in households, ecotourism, recreational, adventure, sports, health, art, heritage tourism, etc.). (Lane, 1994). One of them is agritourism, which is related to households and agricultural production (Tadić \& Veljović, 2020b). In this case, the household is not only a producer of goods but also a creator and provider of tourism services.

Households are significant generators of logistics flows and logistics systems with specific characteristics, attributes and way of functioning. Households that supply goods to other participants in the supply chain realize numerous input, output and internal flows in the process of realization of production (primarily agricultural) (Tadić \& Veljović, 2020a), while agritourism households in addition realize flows related to tourism services (Tadić \& Veljović, 2020b). Therefore, household logistics directly affects the quality of goods and services, or tourism products, and has a very important role in TSC. In direct connection with the concept of household logistics in TSC are the concepts of agri-food supply chain, logistics of agricultural products, rural logistics and logistics of rural tourism, which also significantly affect the quality of tourism products. 
Current, but also epidemics and economic crises that could occur in the future affect primarily international tourism and renowned tourist destinations, while domestic, especially rural and agritourism in some cases even record growth (Vaishar \& Št’astná, 2020), contribute to economic recovery (Piboonrungroj \& Disney, 2009) and represent an opportunity to change the tourism paradigm towards sustainability and local interests (Higgins-Desbiolles, 2020). At the same time, epidemics can increase customers' interest in the origin of goods, especially agri-food, as well as production and logistics processes in the supply chain (Aguiar et al., 2018). Also, the impossibility or difficulty of the realization of flows due to the epidemic can lead to the reaffirmation of local production and short supply chains (Renting et al., 2003). In that case, the logistics of the household as a supplier of goods and services could play an even more significant role in the TSC.

Despite its importance, this topic is very poorly covered in the literature. Although a growing body of research is concerned with TSC management (Guo \& He, 2012; Zhang et al., 2009; Sigala, 2008; Font et al., 2008; Tapper \& Font, 2004) and logistics in tourism (Ajagunna et al., 2017; Muhcina \& Popovici, 2008; Ivanovic \& Baldigara, 2007; Mrnjavac \& Ivanovic, 2007), there is still a very small number of papers dedicated to logistics in rural and agritourism (Tadić \& Veljović, 2020b; Brzozowska et al., 2018; Niedziółka, 2015; 2012), where most of these papers do not fully address the logistics subsystems, processes and activities of the household as participants in the TSC. Households as logistics systems and generators of logistics flows have been analyzed in a very small number of papers (Tadić \& Veljović, 2020a), which do not analyze the role of households in TSC.

This paper analyzes the role of households in TSC, describes the basic characteristics of household logistics in TSC in the context of agricultural production, rural areas and agritourism, as well as the characteristics and importance of individual logistics subsystems. This achieved the basic contribution and goal of the paper. Also, bearing in mind that households participating in TSC as suppliers of goods, services, or complete tourism products often lack education and professional knowledge that would ensure competitiveness and profitability, they can use the ideas presented in the paper to improve their business. Finally, as it establishes a link between supply chains, logistics, tourism, households and agriculture, the paper is a significant contribution to interdisciplinary research on the topic, and a basis for future research.

The paper is organized as follows. The role of the household in the TSC is analyzed below. The third chapter deals with household logistics as a supplier of goods, services or complete tourism products in TSC and its connection with the logistics of agricultural production, rural areas and rural tourism. The fourth chapter describes the basic characteristics and importance of the household logistics subsystem in TSC. The fifth chapter gives directions for future research. Finally, concluding considerations are given.

\section{THE ROLE OF HOUSEHOLDS IN TSC}

TSC is a complex system consisting of different supply chains (Tapper \& Font 2004; Muhcina \& Popovici, 2008; Piboonrungroj \& Disney, 2009). It includes suppliers of all goods and services involved in the delivery of tourism products to customers (Tapper \& Font, 2004). Participants are very connected (March \& Wilkinson 2009; Zhang et al., 2009), so communication (Babu et al., 2018) and coordination in the supply chain is very intensive (Piboonrungroj \& Disney, 2009).

Tour operators (Tadić et al., 2012) play a key role in supply chain management, selling tourism products to customers directly or through travel agencies. They create products by buying tour- 
ism services from the first tier of suppliers (Figure 1). On the other hand, the first tier of suppliers, i.e. tourism service providers uses the goods of second and third-tier suppliers.

Households can be participants in the tourism supply chain at all tiers, in the role of supplier, tour operator or customer (Figure 1). Depending on the place in the supply chain, households partially (suppliers of goods, materials or services) or fully participate in the creation and sale of a tourism product. They can supply other participants with natural resources and other raw materials for agricultural, craft, food or souvenir production (tier 3 suppliers), but also with final products (tier 2 suppliers) and tourism services (tier 1 suppliers). Also, households can perform the functions of tour operators and travel agencies (tier 1 customers) and sell complete tourism products to end customers. Finally, households are very often end customers of tourism products (tier 2 customers).

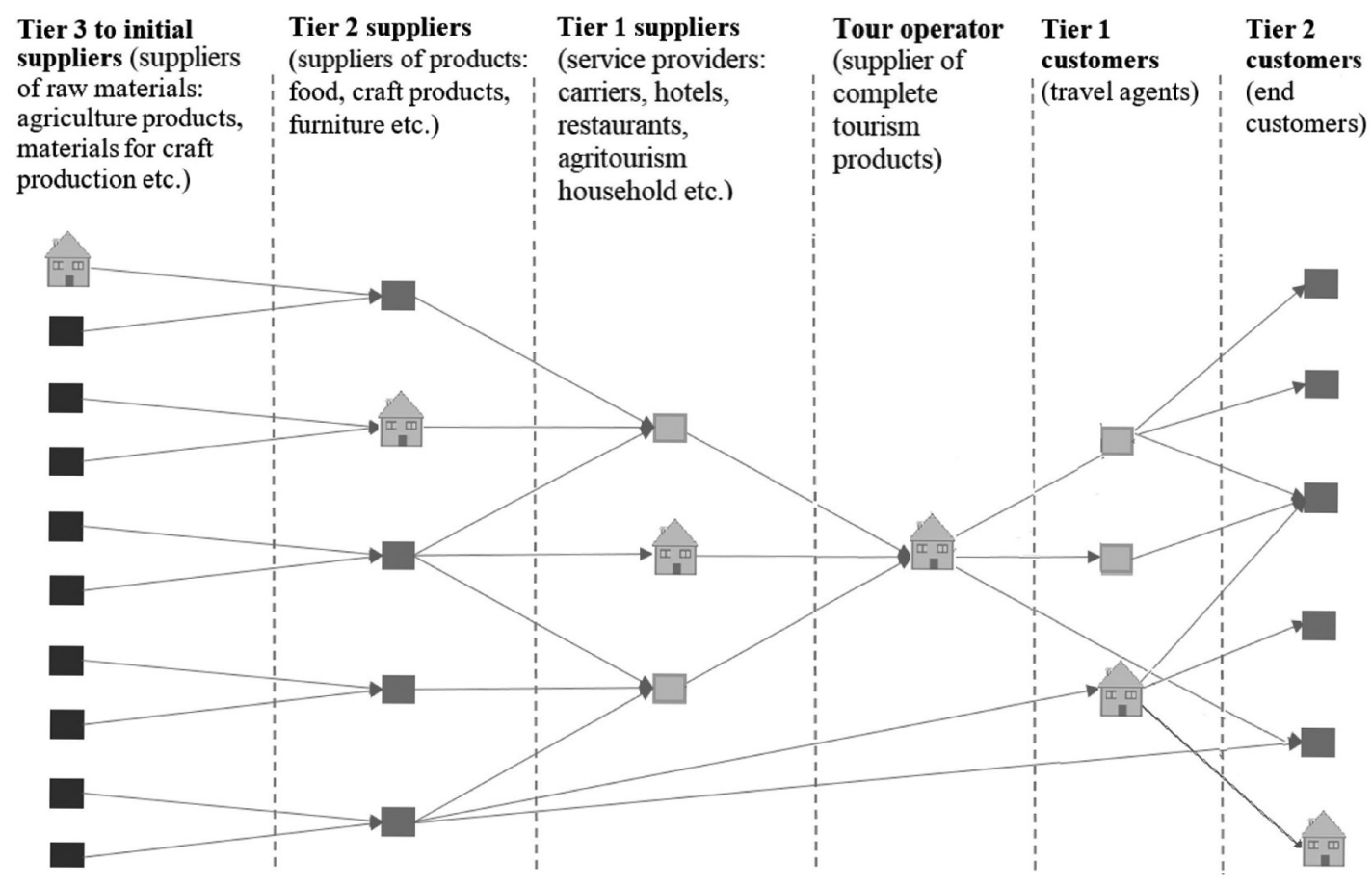

Figure 1. The role of the household in the TSC

Source: revised Tadić et al., 2012

Households most often participate in the production of finished agricultural or food products (Liu et al., 2017), which are consumed within the tourist offer. Therefore, households are very important suppliers in TSC (Font et al., 2008), especially in rural tourism supply chains. Given the specific characteristics and requirements of goods, materials and freights that appear in the flows in the TSC, logistics has a very important role in their realization.

Households can also provide transport, accommodation, food, entertainment services, etc. within the agritourism offer. The material and non-material basis for these services are also provided by household logistics (Tadić \& Veljović, 2020b).

Also, households can supply end customers with complete tourism products. Direct internet sales of agritourism products are increasingly eliminating professional tour operators and travel agencies from the supply chain (Tadić \& Veljović, 2020b), and their functions are taken over by households. In this case, the household provides goods and services and combines them into a 
tourism product that sells directly to end customers. Therefore, household logistics plays a significant role at these tiers of TSC as well.

Finally, the household can be the end customer of tourism products. In this context, the term household is identified with a natural person or family using a tourism product. Given that family tourism has a significant share in tourism activities globally (Schänzel \& Yeoman, 2015), households can be considered as one of the main end customers of tourism products. The role of households as end customers of tourism products will not be discussed in more detail in this paper.

\section{HOUSEHOLD LOGISTICS IN TOURISM}

In recent decades, the number of researches dealing with logistics in tourism has been growing, but it is still insufficient. Szpilko (2017) states that logistics is one of the 11 key areas of research in the field of tourism supply chain management. However, most research in the field of tourism supply chain management is focused on distribution and marketing activities, not taking into account the range of different suppliers involved in creating tourism products in the ,upstream" part of the supply chain (Zhang et al., 2009). It is in this part of the supply chain that households play a significant role. Households can supply other participants with goods, materials, services or complete tourism products, whose quality and continuity of supply directly depend on the realization of logistics flows, processes and activities. The role of logistics of the household as a participant in TSC will be described below.

Logistics has a special significance in the supply of food and agricultural products, which are produced by households in rural areas, but also in the realization of rural and agritourism services. In this context, the terms agri-food supply chain (Blandon et al., 2009), logistics of agricultural products/production (Tan, 2012), rural logistics (Shui-qing, 2006) and logistics of rural tourism (Tadić \& Veljović, 2020b) are particularly important for the analysis of household logistics in TSC (Figure 2). Optimization of flows, processes, activities, infrastructure and technologies within the mentioned areas of logistics contributes to the quality and competitiveness of the tourism offer and products that are partially or completely created by households.

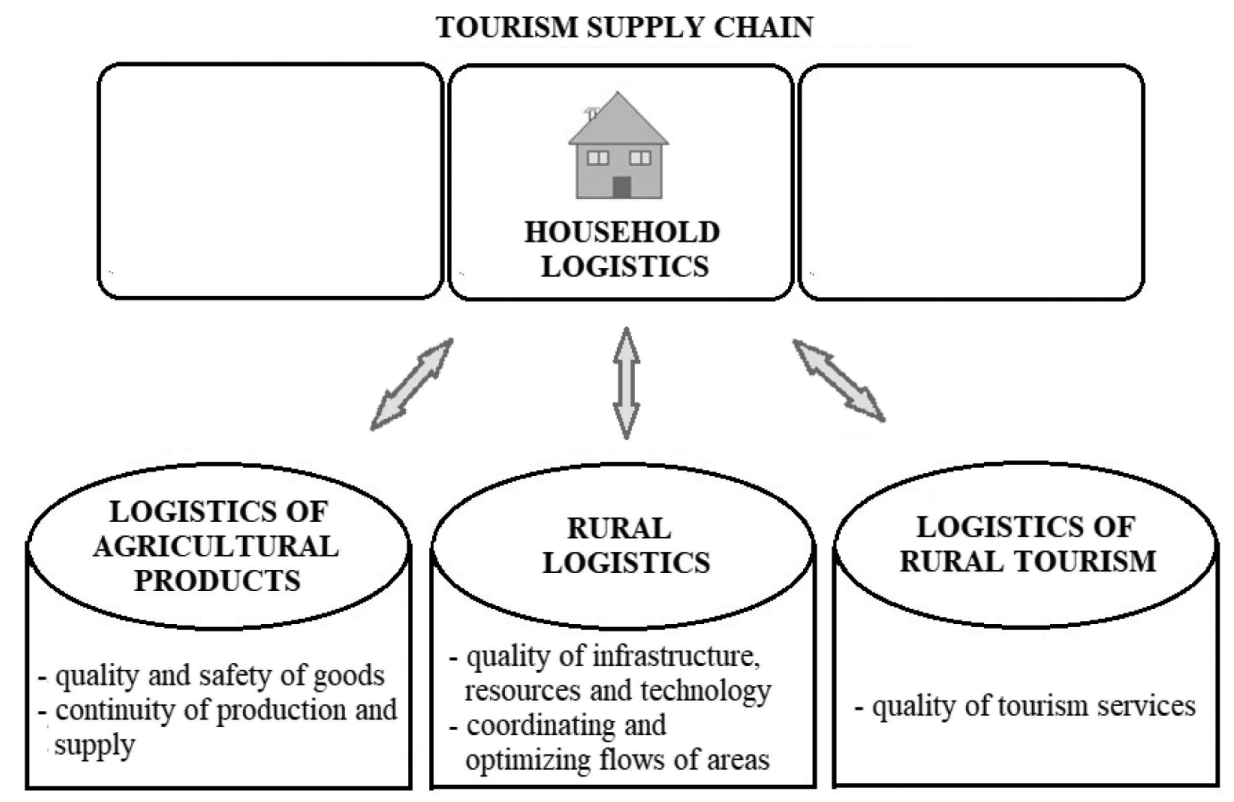

Figure 2. Household logistics in TSC 
The term agri-food supply chains describes activities from production to distribution, by which agricultural or horticultural products (Aramyan et al., 2006) are transferred "from the farm to the table" (Ahumada \& Villalobos, 2009). The production of these goods largely depends on nature and natural resources, which makes management and logistics very complex (Biere, 2001). Such supply chains are especially important in tourism. Gastronomy conveys not only the taste of food but also local cultural experiences (Liu et al., 2017). It is often an essential ingredient of tourism production and consumption (Richards, 2003) and directly affects customer satisfaction. Having in mind the requirements for safety and quality of goods (Grunert, 2005), in the realization of flows of agri-food products, it is necessary to apply modern logistics principles, knowledge and technology. In recent decades, the logistics of agricultural products have attracted increasing attention of researchers (Gebresenbet \& Bosona, 2012; Rokicki, 2013; Caixeta-Filho, 2003; Kramar et al., 2013; Wajszczuk, 2016). Logistics of agricultural products is a branch of the logistics industry, which includes physical and information flows from producers (in this case households) to customers (other participants in TSC), that satisfy consumer demand, including agricultural production, acquisition, transportation, storage, loading and unloading, handling, packaging, distribution processing, distribution, and information activities (Liping, 2009). Logistics costs have a very large share in the total cost of agricultural production (about 40\%) (Tan, 2012; Wajszczuk, 2013). Therefore, logistics plays a central role in modern agricultural production (Federico, 2011), and is based on technology and modern scientific knowledge (Zhang \& Wang, 2011). Technologies such as the Internet of Things, RFID, blockchain, etc. are of increasing importance in the production and distribution of agricultural products (Tian, 2016; Capello et al., 2016; Verdouw et al., 2013). Research and application of knowledge in the field of logistics of agricultural products are of great importance for their quality and competitiveness (Tan, 2012; Qi et al., 2008), and thus the competitiveness of the tourist offer within which they are used for processing or consumption. Also, logistics has a role in maintaining the continuity of agricultural production and supply to customers, meeting their requirements and optimizing costs (Kramar et al., 2013). Logistics and supply chain management largely depends on the type of agricultural products (Biere, 2001). Due to specific requirements, logistics is of particular importance in the production and distribution of perishable agri-food products (meat and dairy products, fresh fruits and vegetables) (Ahumada \& Villalobos, 2009).

Rural logistics is equivalent to the concept of city logistics and includes various logistics activities related to life, production and other socio-economic activities of the population in rural areas (Shui-qing, 2006). The logistical activities of the households-participants of TSC are also included there. In the context of rural areas and households that are participants in the TSC, logistics has a role in ensuring the quality of infrastructure, resources and technology, as well as optimizing, coordinating and efficient realization of flows of customers, goods, materials, freights and information. Although rural logistics can significantly contribute to the progress of rural areas (Liming, 2006), it still attracts significantly less attention from researchers than city logistics (Ji-gang, 2006) and is developing very slowly (Chen \& Zhou, 2011). It is characterized by the divergence of logistics flows, dispersion of their generators, seasonality, etc. (Shui-qing, 2006; Tadić \& Veljović, 2020a; 2020b). Besides, the realization of logistics flows is hampered by poor infrastructure, obsolescence of logistics technologies and low application rates of modern information technologies (Chen \& Zhou, 2011). It is precisely these problems that pose a challenge for household logistics in tourism. Namely, poor technical and technological features of rural logistics can have a very negative impact on the attractiveness of tourism products and destinations and the quality of goods and services. The availability of traffic and logistics infrastructure (different categories of storage systems, different types of logistics units, etc.), transport and logistics services (packaging, storage, marking, labeling, sorting, order picking, etc.) increases mobility and encourages production 
(Gebresenbet and Oodalli, 2005; Gebresenbet \& Bosona, 2012), but also the tourist activity of rural areas. Therefore, governments should attach more importance to improving logistics infrastructure in rural areas and increase investment (Chen \& Zhou, 2011).

The logistics of rural tourism, i.e. agritourism, have the most direct influence on the quality of the tourist offer (Tadić \& Veljović, 2020b). The concept of agritourism is based on a practical economic model that describes the transition from a market-oriented production strategy to a service-oriented sustainability strategy (Liu et al., 2017). Namely, in this case, the rural household is a tourist destination and, in addition to goods, it also provides services to customers. Agritourism services include accommodation, food, entertainment, etc. (Ciolac et al., 2019). Customer satisfaction largely depends on the household as a service provider, as direct contact is made with customers (Yilmaz \& Bititci, 2005; Piboonrungroj \& Disney, 2009). The household as a tourist destination has the characteristics of a logistics system (Mrnjavac \& Ivanovic, 2007). Logistics provides a material (warehouses, means of transport, flows of goods, materials, freights, etc.) and non-material basis (sales, promotion, information flows, etc.) for agritourism services (Tadić \& Veljović, 2020b). During the creation and consumption of tourist products, households realize numerous input, output and internal flows of goods, materials and freights. Logistics activities are present in the procurement or exploitation of raw materials, energy and finished products, promotional and sales activities, transportation of tourists and their personal belongings, the process of providing services to end customers in catering facilities, the realization of reverse flows, etc. (Tadić \& Veljović, 2020b).

The goals of agritourism offer and household logistics can be concordant or conflicting (Figure 3). Customer satisfaction is the main goal of both agritourism offer and household logistics. Namely, the household strives to provide the customer with a tourism product at the right time in the right place under the most favorable conditions (Tadić \& Veljović, 2020b; Tadić et al., 2012; Muhcina \& Popovici, 2008), using logistics as the basic instrument. The tourism product in rural and agritourism has a distinct local character in terms of supply, production, consumption, characteristics of goods, services, etc. Thus, in the preparation and during the performance of tourist activity, the household usually uses locally available natural raw materials (e.g. wood), goods from its production, existing storage facilities, etc. (Tadić \& Veljović, 2020b). This contributes to the reduction of logistics costs through the reduction of distances covered, consolidation of flows, utilization of existing storage capacities, etc. On the other hand, goals are sometimes conflicting. In order to achieve logistical efficiency, modern technical and technological solutions are applied, which can disrupt the traditional spirit and environment in which tourist services should be realized. Therefore, it is necessary to achieve a tradeoff between these goals and offer customers the optimal combination of traditional and modern features, in accordance with their needs, desires and expectations.

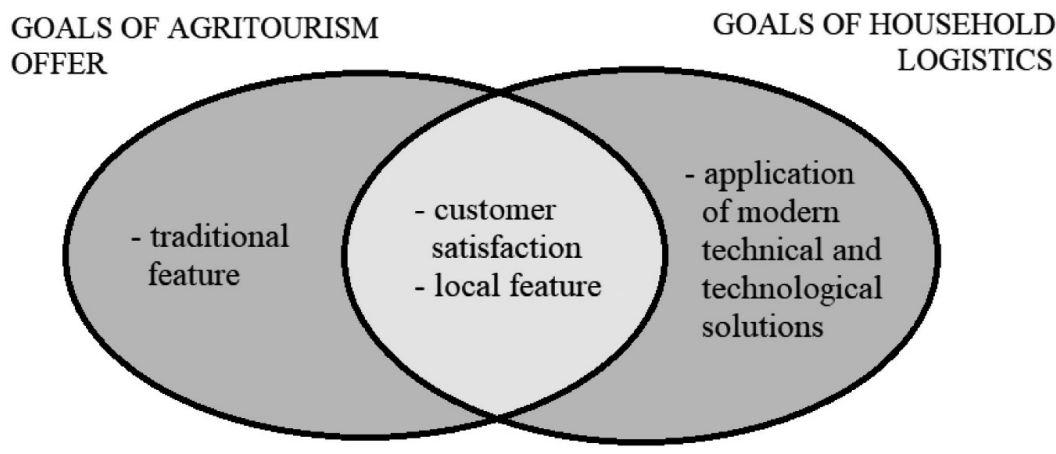

Figure 3. Goals of agritourism offer and household logistics 


\section{HOUSEHOLD LOGISTICS SUBSYSTEMS}

The quality of the tourism product, which is partially or completely created and sold by the household, depends on the quality of infrastructure, resources and technologies of the household logistics subsystems, as well as connecting, coordinating and synchronizing processes and activities that are realized within them. The basic characteristics of the logistics subsystems of ordering, transport, inventory management, warehousing and packaging in the context of the role of the household in TSC as a supplier of goods, services or complete tourism products will be described below.

\subsection{Ordering, promotion and other information flows}

The household as a supplier of goods, services or complete tourism products in TSC has intensive communication with other participants. In the first case, information flows follow the planning, organization and realization of the production of goods and the supply of other participants in the supply chain. Ordering goods, agreements on the dynamics and quantity of delivery are realized through modern ICT.

Also, information flows play a very important role in the promotion and sale of services and products of agritourism households. Nowadays, the promotion and reservation of household capacities are most often realized via the Internet, but tourist and gastronomic fairs and events, as well as the distribution of promotional material (brochures, guides, etc.) also play a very important role (Tadić \& Veljović, 2020b).

\subsection{Transport}

Bearing in mind the necessity of intensive realization of transport flows, the German agronomist Albrecht Thaer stated in 1813 that a rural household/farm was inadvertently a transport company (Wolszczan, 1988; Wajszczuk, 2016). Rural households realize numerous transport flows, primarily in the process of realization of agricultural production. Transport costs have a very high share in the total logistics costs of a household engaged in agricultural production (Ongkunaruk \& Piyakarn, 2011; Wajszczuk, 2013). The additional increase in transport activities is contributed by the engagement of households in TSC. In this case, except in agricultural production, transport flows are realized in order to supply other participants in the supply chain and provide agritourism services.

Both passenger and freight transport are important for TSC. Passenger transport provides unhindered movement of tourists (Fawcett, 2000; Duval, 2007; Piboonrungroj \& Disney, 2009), and freight transport provides unhindered movement of goods, materials and freights between participants in the supply chain, primarily between suppliers of goods, materials (input providers) and service providers (Véronneau \& Roy, 2009; Piboonrungroj \& Disney, 2009). The characteristics of freight transport realized by households in TSC will be described below, while passenger transport will not be discussed in more detail.

The analysis of transport in the context of TSC is important from the aspect of the quality of tourism products, but also the economic, ecological and ethical aspects. Adequate means of transport, infrastructure and operation management should enable safe transport and preservation of the quality of goods, materials and freights. For households supplying other participants 
in TSC agri-food products, transport infrastructure is a significant factor of success and competitiveness (Caixeta-Filho, 2003). Many agricultural households have little chance of success in the market because their marketing activities are hampered by the use of inadequate or poor means of transportation (Gebresenbet \& Bosona, 2012). Also, great challenges for these households are (Wajszczuk, 2016): high costs of internal transport, heterogeneity of goods, materials and freights, which generates the need for different means of transport and transport conditions, large volume and number of transport flows, empty trips, short distances and poor transport infrastructure, the low transport capacity of perishable agricultural products and high risk of losses, etc. In recent decades, increasing importance has been given to the analysis of the impact of transport on the environment, pollution and noise. Therefore, households in TSC must also take into account the environmental aspect in the planning, organization and implementation of transport flows.

Transport also plays an important role for agritourism households, both in the preparation phase and during the tourist activity. A special challenge is the delivery of old buildings and ethnographic exhibits, having in mind the specific characteristics and requirements for preserving their integrity, quality and authenticity (Tadić \& Veljović, 2020b). Transport can be an area of conflict of goals between agritourism offer and household logistics, i.e. traditional and modern characteristics, but also a problem from the ethical aspect. Namely, in some countries, traditional methods of transport are still used, which involve the engagement of human or animal strength (e.g. head loading, using animals to pull carts or sledges, using pack animals, etc.) (Gebresenbet \& Bosona, 2012). Such methods can be attractive to tourists, sometimes economically justified, and very often in line with environmental imperatives. However, some of them do not meet modern criteria of logistical efficiency (limited quantity of cargo, low transport speed, inadequate transport of perishable goods, etc.; Gebresenbet \& Bosona, 2012), as well as health or ethical criteria related to human and animal welfare, which should be taken into account when planning the transport subsystem.

\subsection{Inventory management}

Depending on the role in the TSC, households manage different inventory. Households that realize agricultural production for the needs of their tourist offer or supply goods to other participants usually have an inventory of agricultural products, goods and materials needed for the process of agricultural production, logistics units and packaging materials, etc. Agricultural production has a seasonal character and is realized mainly during the warmer part of the year. Households in the TSC must provide inventory for the rest of the year, to ensure continuity of supply and consumption. Therefore, large quantities of inventory are formed in a short time (Wajszczuk, 2016). Inventory management costs account for $12.2 \%$ of the total logistics costs of agricultural production (Wajszczuk, 2013). Agritourism households, in addition to the above, most often have the inventory needed for accommodation (bedding, towels, chemicals for hygiene and cleaning, etc.), food services (groceries, dishes, etc.), entertainment (sports equipment, books, etc.). The application of various theoretical models and modern technologies can support efficient inventory management in the household (Tadić \& Veljović, 2020b).

\subsection{Warehousing}

Efficient inventory management requires adequate facilities, equipment and storage technologies. The characteristics of the warehouse/storage subsystem depend on the type of goods, materials. Agricultural and food products as the most important household stocks in TSC are usually 
easily perishable, so it is necessary to provide special conditions for their storage and protection from harmful physical, chemical and biological influences. On the other hand, non-perishable agricultural products such as cereals, potatoes and nuts can be stored longer, without special conditions (Ahumada \& Villalobos, 2009). Since seasonality causes the need to form large stocks, it is often necessary to provide a very large storage space (Wajszczuk, 2016). Apart from the purpose of keeping stock, storage is in some cases realized as part of the production process (e.g. ripening of brandy and wine, drying of meat and fruit) (Tadić \& Veljović, 2020b).

The characteristics of the household warehouse subsystem also depend on its role in the TSC. The household that is the supplier of the goods must take into account only the logistical aspect of planning the warehouse system. On the other hand, the agritourism household must take into account the perception of tourists. In that case, warehousing can be an area of conflict between the goals of the tourist offer and household logistics and requires the establishment of their balance. First of all, it is necessary to harmonize traditional architectural-construction and modern logistical goals. Old buildings (e.g. wooden buildings covered with straw or shingles, basements, etc.) are often used for storage, which can positively affect the tourist offer, but it is necessary to renovate them in order to be purposeful and functional. In case a new storage facility is built, its appearance (primarily exterior) should also be adjusted to the archaic ambience of the household.

Similar challenges are related to storage equipment and technologies. Traditional storage equipment and methods (e.g. storage of dried meat in grain, storage of dairy products in wooden utensils or stuffed animal skins, etc.) can contribute to the authenticity and quality of the tourist offer. Thus, the traditional method of storing fruit in straw provides a specific aroma that can be attractive to tourists (Dorobanţu \& Nistoreanu, 2012). However, even in this case, the basic criteria of logistical efficiency, safety and quality of goods should be taken into account.

Educating household members on storage process management is very important. Namely, their training can significantly reduce losses incurred during the storage of goods (Gebresenbet \& Bosona, 2012).

\subsection{Packaging}

The management of the packaging subsystem should be taken into account in the development of agricultural logistics systems (Gebresenbet \& Bosona, 2012), as well as the household logistics system in TSC. Packaging of goods produced by the household is very important for its sale and should provide information to customers, recognizability of the indigenous product, sustainability of its quality and the possibility of proper storage (Tadić \& Veljović, 2020b).

Lack of packaging capacity may be one of the limitations in the logistics system of households during the transition from own-account production to commercial agricultural production (Gebresenbet \& Bosona, 2012). Product packaging contains information on the origin, production process and quality of goods. Also, packaging has a protective function, since significant losses occur due to mechanical damage to agricultural products (Ferris et al, 1993). Although the introduction of packaging can contribute to the recognition and sale of products, in this way the amount of packaging waste increases (Tadić \& Veljović, 2020b), which should be borne in mind when planning the packaging subsystem. 


\section{FUTURE RESEARCH DIRECTIONS}

Given that the paper is a significant contribution to interdisciplinary research on the topic, which is insufficiently addressed in the literature, it can be the basis for numerous future researches. The optimization of the logistics processes of the household in TSC in the context of the relationship between transport and inventory costs, logistics costs and the quality of the tourist offer, can be the subject of the research. Also, it is necessary to do a detailed analysis of the characteristics of the logistics system and technologies of the traditional household, their applicability and efficiency in modern agricultural production and tourism. On the other hand, the application of modern technical-technological solutions and their adaptation in the context of harmonization of the goals of agritourism offer and household logistics can also be the subject of future research.

\section{CONCLUSION}

The household can be a TSC participant at all tiers: as a supplier of goods, materials, services, complete tourism products (tour operator/travel agency) or end customer. The quality and competitiveness of tourism products, which partially or completely create and sell by households, depends on the optimization of physical, flows of information and customers. Efficient realization of these flows is enabled by logistics systems, technologies and application of logistics principles. Therefore, household logistics can play a very important role in TSC, especially in rural and agritourism.

This paper analyzes the role of households in TSC, describes the basic characteristics of household logistics in TSC in the context of agricultural production, rural areas and agritourism, as well as the characteristics and importance of individual logistics subsystems. This achieved the basic contribution and goal of the paper.

\section{REFERENCES}

Aguiar, L. C., DelGrossi, M. E., \& Thomé, K. M. (2018). Short food supply chain: characteristics of a family farm. Ciência Rural, 48(5). https://doi.org/10.1590/0103-8478cr20170775

Ahumada, O., \& Villalobos, J. R. (2009). Application of planning models in the agri-food supply chain: A review. European Journal of Operational Research, 196(1), 1-20. https://doi.org/10.1016/j. ejor.2008.02.014

Ajagunna, I., Pinnock, F., \& Amode, T. M. (2017). Tourism development and logistics in the Caribbean: Will there be a symbiotic relationship?. Worldwide Hospitality and Tourism Themes, 9(1), 116-123. https://doi.org/10.1108/WHATT-11-2016-0071

Aramyan, C., Ondersteijn, O., Van Kooten, O., \& Lansink, A. O. (2006). Performance indicators in agri-food production chains. In Ondersteijn, C. J. M., Wijnands, J. H. M., Huirne, R. B. M., Van Kooten, O. (Eds.), Quantifying the Agri-Food Supply Chain (pp. 49-66). Springer, Netherlands

Babu, D. E., Kaur, A., \& Rajendran, C. (2018). Sustainability practices in tourism supply chain. Benchmarking: An International Journal, 25(4), 1148-1170. https://doi.org/10.1108/BIJ-06-2016-0084

Biere, A.W. (2001). Agribusiness logistics: An emerging field in agribusiness education. In IAMA World Food and Agribusiness Symposium, Sydney, Australia

Blandon, J., Henson, S., \& Cranfield, J. (2009). Small-scale farmer participation in new agri-food supply chains: Case of the supermarket supply chain for fruit and vegetables in Honduras. Journal of International Development, 21(7), 971-984. https://doi.org/10.1002/jid.1490 
Brzozowska, A., Kalinichenko, A., Niedziółka, A., \& Popławski, Ł. (2018). Logistic procedures in the promotion of agritourism, Infrastructure and Ecology of Rural Areas, 4(1), 891-907. https://doi. org/10.14597/INFRAECO.2018.4.1.061

Caixeta-Filho, J. V. (2003). Transportation and Logistics in Brazilian Agriculture, Paper presented at the Agricultural Outlook Forum, U.S. Department of Agriculture, Arlington, VA, February 20, 2003.

Capello, F., Toja, M., \& Trapani, N. (2016). A real-time monitoring service based on industrial internet of things to manage agrifood logistics. Paper presented at 6th International Conference on Information Systems, Logistics and Supply Chain (ILS Conference 2016), June 1-4, Bordeaux, France (pp. 1-8)

Chen, X., \& Zhou, J. (2011). The Research on the Interaction Effects of Rural Logistics and Economic Development [C]. Paper presented at 13th International Conference on Enterprise Information Systems (ICEIS-2011) (pp. 167-171). https://doi.org/10.5220/0003487501670171

Ciolac, R., Adamov, T., Iancu, T., Popescu, G., Lile, R., Rujescu, C., \& Marin, D. (2019). Agritourism A Sustainable Development Factor for Improving the "Health" of Rural Settlements. Case Study Apuseni Mountains Area, Sustainability 11(5), 1467-1490. https://doi.org/10.3390/su11051467

Dorobanţu, M.R., \& Nistoreanu, P. (2012). Hospitality - a component of Romanian Rural Tourism Products, Cactus Tourism Journal, 3(2), 17-23.

Duval, D.T. (2007). Tourism and Transport: Modes, Networks and Flows. Clevedon, UK: Channel View Publications.

Fawcett, P. (2000). Managing Passenger Logistics: The Comprehensive Guide to People and Transport. London, UK: Kogan Page.

Federico S. (2011). The modern agricultural frontier and logistics: the importance of the soybean and grain storage system in Brazil. TERRA, 8(1-2), 26-34.

Ferris, R.S.B., Hotsonyame, G.K., Wainwright, H., \& Thompson, A.K. (1993). The effects of genotype, damage, maturity, and environmental conditions on the postharvest life of plantain. Tropical Agriculture, 70(1), 45-50.

Font, X., Tapper, R., Schwartz, K., \& Kornilaki, M. (2008). Sustainable supply chain management in tourism. Business Strategy and the Environment, 17(4), 260-271. https://doi.org/10.1002/bse.527

Gebresenbet, G, \& Bosona, T. (2012). Logistics and Supply Chains in Agriculture and Food, In Groznik, A. (Ed.), Pathways to Supply Chain Excellence (pp. 125-146). https://doi.org/10.5772/25907

Gebresenbet, G., \& Oodally, G. (2005). Review and analysis of rural agricultural transport and logistics in developing countries: Technical Guidelines. Report, Swedish University of Agricultural Sciences

Grunert, K.G. (2005). Food quality and safety: Consumer perception and demand. European Review of Agricultural Economics, 32(3), 369-391. https://doi.org/10.1093/eurrag/jbi011

Guo, X., \& He, L. (2012). Tourism Supply-Chain Coordination: The Cooperation between Tourism Hotel and Tour Operator. Tourism Economics, 18(6), 1361-1376. https://doi.org/10.5367/te.2012.0179

Higgins-Desbiolles, F. (2020). Socialising tourism for social and ecological justice after COVID-19. Tourism Geographies, 22(3), 610-623 https://doi.org/10.1080/14616688.2020.1757748.

Ivanovic, Z., \& Baldigara, T. (2007). Logistics Processes in a Tourism Destination. Tourism and Hospitality Management, 13(3), 595-606.

Jafari, J. (1974). The components and nature of tourism. The tourism market basket of goods and services. Annals of Tourism Research, 1(3), 73-89. https://doi.org/10.1016/0160-7383(74)90034-6

Ji-gang, W. (2006). Reference, Experience and Characteristic of Logistics Development in Developed Countries. China Business and Market, 10, 15-18.

Kochadze, T., Dangadze, I., \& Zaqareishvili, V. (2013). The role of logistics in the market for transportation and tourist services. Machines, Technologies, Materials, 4, 1-3. 
Kramar, U., Topolšek, D., \& Lipičnik, M. (2013). How to define logistics in agriculture? http://www. kgau.ru/new/all/konferenc/konferenc/2013/e8.pdf

Lane, B. (1994). What is rural tourism?. Journal of Sustainable Tourism, 2(1-2), 7-21. https://doi. org/10.1080/09669589409510680

Li-ming, H. (2006). General Review of the Development of China Logistics Industry in 2005 and the Perspective of 2006. China Logistics \& Purchasing, 4, 18-21.

Liping, W. (2009). Study on Agricultural Products Logistics Mode in Henan Province of China. School of Economics and Management, Henan Polytechnic University, China

Liu, S. Y., Yen, C. Y., Tsai, K. N., \& Lo, W. S. (2017). A Conceptual Framework for Agri-Food Tourism as an Eco-Innovation Strategy in Small Farms. Sustainability, 9(10), 1683-1693. https://doi. org/10.3390/su9101683

March, R., \& Wilkinson, L. (2009). Conceptual tools for evaluating tourism partnerships. Tourism Management, 30(3), 455-462. https://doi.org/10.1016/j.tourman.2008.09.001

Mathieson, A., \& Wall, G. (1982). Tourism: Economic, physical and social impacts. New York: Longman Scientific \& Technical.

Mrnjavac, E., \& Ivanovic, S. (2007). Logistics and logistics processes in a tourism destination. Tourism and Hospitality Management, 13(3), 531-546.

Muhcina, S., \& Popovici, V. (2008). Logistics and Supply Chain Management in Tourism. Amfiteatru Economic, 10(24), 122-132.

Niedziółka, A. (2012). Logistyka w działaniach wybranych podmiotów i instytucji w sferze promocji agroturystyki na przykładzie województwa małopolskiego. Logistyka, 4, 1135-1142.

Niedziółka, A. (2015). Transfer of information in agritourism using portals as parts of the logistics management of rural areas, In: Brzozowska, A., Kalinichenko, A.V. (Ed.), Transformation management of economic at rural areas (pp. 223-230). Poltava: State Agrarian Academy.

Ongkunaruk, P., \& Piyakarn, C., (2011). Logistics Cost Structure for Mangosteen Farmers in Thailand. System Engineering Procedia, 2, 40-48. https://doi.org/10.1016/j.sepro.2011.10.006

Page, S. (2009). Tourism Management. 3rd ed. London: Elsevier.

Piboonrungroj, P., \& Disney, S. M. (2009). Tourism Supply Chains: A Conceptual Framework. PhD Networking Conference - Exploring Tourism III: Issues in PhD Research (pp. 1-11)

Qi, Y. B., Yang, J. J., \& Tang, Y. J. (2008). Agricultural Logistics: Situation, Problem and Countermeasure. Journal of Sichuan Agricultural University.

Renting, H., Marsden, T. K., \& Banks, J. (2003). Understanding Alternative Food Networks: Exploring the Role of Short Food Supply Chains in Rural Development. Environment and Planning A, 35(3), 393-411. https://doi.org/10.1068/a3510

Richards, G. (2003). Gastronomy: An essential ingredient in tourism production and consumption?. In Hjalager, A. M., \& Richards, G. (Eds.), Tourism and Gastronomy (pp. 3-20). London, UK: Routledge.

Rokicki, T. (2013). The Importance of Logistics in Agribusiness Sector Companies in Poland, Paper presented at International Scientific Conference Economic Science for Rural Development, Jelgava (pp.116-120).

Schänzel, H. A., \& Yeoman, I. (2015). Trends in family tourism. Journal of Tourism Futures, 1(2), 141-147. https://doi.org/10.1108/JTF-12-2014-0006

Shui-qing, X. (2006). The Content and Features of Rural Logistics [J]. Journal of Chongqing Jiaotong University, 9, 51-53.

Sigala, M. (2008). A supply chain management approach for investigating the role of tour operators on sustainable tourism: the case of TUI. Journal of Cleaner Production, 16(15), 1589-1599. https:// doi.org/10.1016/j.jclepro.2008.04.021 
Szpilko, D. (2017). Tourism Supply Chain-Overview of Selected Literature. Procedia Engineering, 182, 687-693. https://doi.org/10.1016/j.proeng.2017.03.180

Tadić, S., \& Veljović, M. (2020a). Logistics flow of household. Tehnika, 75(2), 225-237. https://doi. org/10.5937/tehnika2002225T

Tadić, S., \& Veljović, M. (2020b). Logistics of rural tourism. International journal for traffic and transport engineering - IJTTE, 10(3), 323-350. http://dx.doi.org/10.7708/ijtte.2020.10(3).06

Tadić, S., Zečević, S., \& Krstić, M. (2012). Logistics and Supply Chain Management in tourism: Present state and limitations. Tehnika, 67(6), 1018-1025.

Tan, D. (2012). Developing Agricultural Products Logistics in China from the Perspective of Green Supply Chain. International Journal of Business and Management, 7 (21), 106-112. https://doi. org/10.5539/ijbm.v7n21p106

Tapper, R., \& Font, X. (2004). Tourism supply chains: Report of a desk research project for the travel foundation. Leeds Metropolitan University, Environment Business \& Development Group.

Tian, F. (2016). An agri-food supply chain traceability system for China based on RFID and blockchain technology. Paper presented at 13th international conference on service systems and service management (ICSSSM), Kunming, China, June 24-26, 2016. http://dx.doi.org/10.1109/ ICSSSM.2016.7538424

United Nations - World Tourism Organization, Recommendations on Tourism Statistics 1994, Series M, No 83

Vaishar, A., \& Štastná, M. (2020). Impact of the COVID-19 pandemic on rural tourism in Czechia. Preliminary considerations, Smart countryside for the $21^{\text {st }}$ century, Paper presented at 7 th Moravian Conference on Rural Research EURORURAL '20, (pp. 37-39). https://doi.org/10.1080/1368350 0.2020 .1839027

Verdouw, C., Sundmaeker, H., Meyer, F., Wolfert, J., \& Verhoosel J. (2013). Smart agri-food logistics: requirements for the future internet. In Kreowski, H. J., Scholz-Reiter, B., \& Thoben, K.D. (Ed.), Dynamics in Logistics (pp. 247-257). Springer. https://doi.org/10.1007/978-3-642-35966-8_20

Véronneau, S., \& Roy, J. (2009). Global service supply chains: An empirical study of current practice and challenges of a cruise line corporation. Tourism Management, 30(1), 128-139. https://doi. org/10.1016/j.tourman.2008.05.008

Wajszczuk, K. (2013). Model rachunku kosztów logistyki dla przedsiębiorstw rolniczych, Wyd. UP w Poznaniu, Poznań

Wajszczuk, K. (2016). The Role and Importance of Logistics in Agri-Food Supply Chains: An Overview of Empirical Findings. Logistics and Transport, 2(30), 47-55.

Wolszczan J. (1988). Transportochłonność rolnictwa. Zesz. Probl. Post. Nauk Rol., 348, pp. 35-41.

Yilmaz, Y., \& Bititci, U. (2005). Performance measurement in the value chain: manufacturing v. tourism. International Journal of Productivity and Performance Management, 55(5), 371-389. https:// doi.org/10.1108/17410400610671417

Zhang, X., \& Wang, C. (2011). Application of Analytic Network Process in Agricultural Products Logistics Performance Evaluation, Department of Economy and Management, Tianjin University of Finance \& Economics, Tianjin, China

Zhang, X., Song, H., \& Huang, G. Q. (2009). Tourism supply chain management: A new research agenda. Tourism Management, 30(3), 345-358. https://doi.org/10.1016/j.tourman.2008.12.010

Zhang, Y., \& Murphy, P. (2009). Supply-chain considerations in marketing underdeveloped regional destinations: A case study of Chinese to Goldfields region of Victoria. Tourism Management, 30(2), 278-287. https://doi.org/10.1016/j.tourman.2008.07.004 